\title{
Ultrasonographic differentiation of the peripheral choroidal detachment from the circumferential scleral buckle
}

\author{
Amar Pujari, Rohan Chawla
}

Department of Ophthalmology, Dr. Rajendra Prasad Centre for Ophthalmic Sciences, AlIMS, Delhi, India

Correspondence to Dr Amar Pujari, dramarpujari@gmail.com

Accepted 25 February 2018

\section{DESCRIPTION}

A 40-year-old male patient presented with a history of surgery in the left eye for retinal detachment 1 year ago. His history of medical and surgical interventions was incomplete as the patient lost all his previous records. On examination, visual acuity was 20/20 in the right eye and hand movement close to face with accurate projection of rays in the left eye. Both eye corneas were clear with normal anterior chambers. The right eye had a clear lens, and the fundus was within normal limits. Whereas in the left eye, a total cataract was present. This hindered the retinal evaluation. Intraocular pressures were $18 \mathrm{~mm} \mathrm{Hg}$ in the right eye and $14 \mathrm{~mm}$ $\mathrm{Hg}$ in the left eye. To assess the posterior segment,
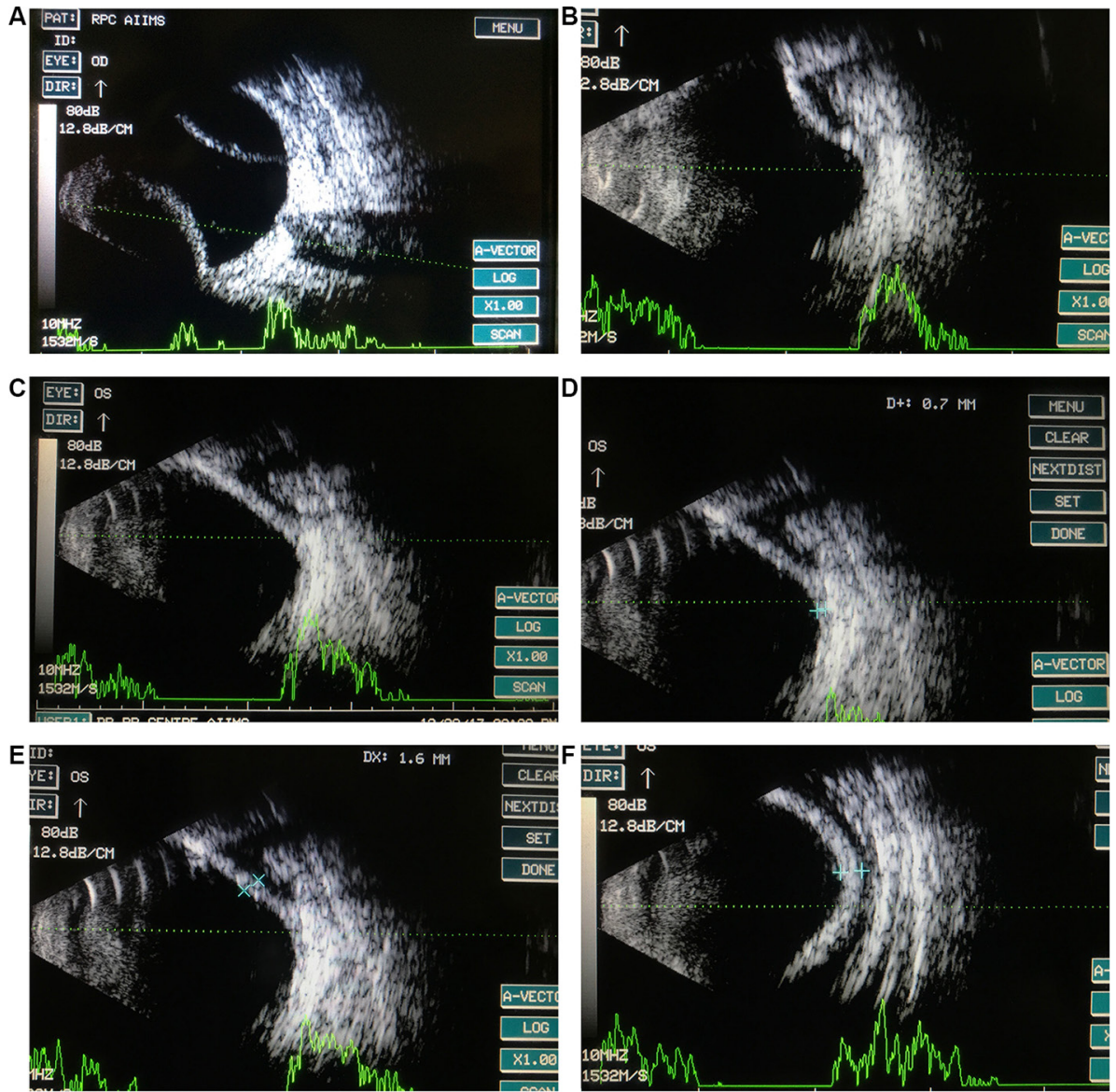

Figure 1 (A) A typical case of choroidal detachment showing large convex mount extending from the ora serrata to the equator. (B) Peripheral shallow convex mount confounding as choroidal detachment. (C) Along the oblique plane, the convex mount assuming a more flat configuration. (D) Along the oblique plane, the choroidal thickness is measured in its attached part. (E) The thickness of the convex mount was measured along the oblique plane. (F) Along the horizontal transverse plane, a hallow corresponding with the circumferential buckle can be appreciated. 
found to be $1.7 \mathrm{~mm}$ (figure $1 \mathrm{E}$ ), suggestive of thicker coat due to all three layers (retina, choroid and the sclera). Third, if the probe is placed along the horizontal transverse position, a circumferential hypoechoic space was noted behind the thick ocular coat, and now the convexity faces away from the vitreous cavity (figure $1 \mathrm{~F}$ ). These findings were suggestive of circumferential indenting structures, likely to be a scleral buckle.

By measuring the thickness of the choroid and the choroidal like mount due to convex appearing ocular coat along with a circumferential appreciation of hypoechoic space behind the thick ocular coat helps in differentiating the peripheral choroidal detachment from the pseudo-appearance of choroidal detachment due to a circumferential buckle.

Optimal diagnosis of the posterior segment pathologies is of paramount importance in cases of anterior segment media opacities because the posterior segment is the potential site which may harbour vision as well as life-threatening diseases. Choroidal detachment is a significant posterior segment pathology which

Learning points

Differentiation of peripheral choroidal detachment from other forms of clinically as well as radiologically misleading conditions is vital.

- While evaluating such cases measuring the thickness of convex mount and the choroidal thickness using B scan ultrasonography is useful in ascertaining the final diagnosis. needs a definite diagnosis before proceeding for any form of ocular interventions. B scan ultrasound is a useful tool to assess the far peripheral retinal pathologies along the lateral longitudinal view. ${ }^{1}$ The choroidal mount will have a double spike with convexity towards the vitreous with or without any suprachoroidal collections. The shallow choroidal detachment is seen in ocular hypotonic conditions like post-trabeculectomy surgery, post-traumatic globe injuries, postretinal detachment surgeries and corneal ulcerations accompanied by spontaneous perforation. In all such conditions, choroidal detachment may downgrade the visual prognosis, thus differentiation of choroidal detachment from other masquerades is vital.

Contributors AP and RC have evaluated the case in detail followed by optimal diagnosis for further management. AP and RC after critically evaluating the educational value of the case wrote the report together.

Funding This research received no specific grant from any funding agency in the public, commercial or not-for-profit sectors.

Competing interests None declared.

Patient consent Obtained.

Provenance and peer review Not commissioned; externally peer reviewed.

(c) BMJ Publishing Group Ltd (unless otherwise stated in the text of the article) 2018. All rights reserved. No commercial use is permitted unless otherwise expressly granted.

\section{REFERENCE}

1 Pujari A, Swamy DR, Chawla R, et al. Simple way to optimise ultrasonographic visualisation of the retinal periphery and anterior segment structures. BMJ Case Rep 2017;2017:bcr2017219287.

Copyright 2018 BMJ Publishing Group. All rights reserved. For permission to reuse any of this content visit http://group.bmj.com/group/rights-licensing/permissions.

BMJ Case Report Fellows may re-use this article for personal use and teaching without any further permission.

Become a Fellow of BMJ Case Reports today and you can:

- Submit as many cases as you like

- Enjoy fast sympathetic peer review and rapid publication of accepted articles

- Access all the published articles

Re-use any of the published material for personal use and teaching without further permission

For information on Institutional Fellowships contact consortiasales@bmjgroup.com

Visit casereports.bmj.com for more articles like this and to become a Fellow 